Tér és Társadalom 16. évf. 2002/1. 161-164. p.

Tér és Társadalom

XVI. évf. 2002 1: $161-177$

KöNYVJELZÖ

\title{
ILLÉS IVÁN: KÖZÉP- ÉS DÉLKELET-EURÓPA AZ EZREDFORDULÓN ÁTALAKULÁS, INTEGRÁCIÓ, RÉGIÓK
}

(Dialóg Campus, Budapest-Pécs, 2002. Studia Regionum. Területi és Települési Kutatások, 19. kötet. 362 o.)

\section{KOVÁCS TERÉZ}

Közép- és Délkelet-Európa átfogó elemzéséröl nem készült még monográfia hazánkban. Most ezt a hiányt pótolta sikeresen Illés Iván, aki ezúttal saját kutatásainak eredményeit, sokoldalú tapasztalatait foglalta össze. A könyv megszületését mégis jelentős részben egy konkrét kutatási-tervezési projektnek köszönheti. A Szerző 1997-1999 között három évet töltött Bonnban a német Szövetségi Építési és Területfejlesztési Hivatalban mint a közép- és délkelet-európai integrált térségfejlesztés stratégiájának kidolgozását célzó nemzetkőzi projekt tudományos tanácsadója. Ez a munka adta az indítékot a 18 ország vizsgálatba való bevonásához, amely hatalmas, mintegy 1275,7 ezer $\mathrm{km}^{2}$ területet és 138,2 millió fỏ lakosságot foglal magában. Ezek az országok, illetve országrészek:

Albánia
Ausztria
Bosznia-Hercegovina
Bulgária
Csehország
Görögország
Horvátország
Jugoszlávia
Lengyelország

Macedónia
Magyarország
Moldova
Dél-és Kelet-Németország
Adriai-Olaszország
Románia
Szlovákia
Szlovénia
Nyugat-Ukrajna

A fenti térséget nevezi Illés Iván Közép- és Kelet-Európának, és első pillanatra talán zavarónak tủnik, hogy egyes nagyobb országok (Németország, Olaszország és Ukrajna) esetében nem az állam egész területét, hanem annak csak egy részét tette elemzésének tárgyává. Az olvasó azonban hamar rájön, hogy ezeknek az országoknak a vizsgálatba került régiói szervesen kapcsolódnak a térség többi országaihoz. Nem a földrajzi jellemzök, hanem a történelem és a politika az, ami összekapcsolja Kelet-Közép-Európát - írja Illés Iván.

A könyv négy fejezetböl áll, de szerkezetileg végül is két részre osztható. Az egyik részt az első három fejezet képezi. E fejezeteknek rövid, frappáns címei van- 
Tér és Társadalom 16. évf. 2002/1. 161-164. p.

nak: az Örökség, a Kihívás és a Perspektíva. Ebben a részben a közép- és délkeleteurópai régiók fejlödésének és differenciálódásának gazdag elemzésével találkozunk.

Illés Iván azok közé tartozik, akik „rövid XX. századról” beszélnek, amely 1920-tól 1990-ig tartott. Vizsgálatát gyakran erre az egész századra kiterjeszti. Érdekes és olvasmányos formában tárja elénk azt, hogy a régió egyes országai hogyan vetélkedtek és harcoltak egymással a tengerekhez való kijáratért, milyen fontos szerepe volt az etnikai és a vallási hovatartozásuknak a térségben felmerülö problémák megjelenésében. Ennek kapcsán az olvasó az egyes országokról és régiókról a helyi részletekbe menőkig betekintést kap.

A Szerző kiemeli, hogy Közép- és Délkelet-Európa országainak gazdasága instabil és elmaradott, a demokrácia még gyenge, az országok egymással való kapcsolatában feszülttségek vannak. Továbbá megállapítja, hogy a reformfolyamatok legnagyobb ellenzöi a társadalmi átalakulás vesztesei közül kerülnek ki. Illetve, hogy a térség lakónépességének száma úgy alakult, hogy a gazdag országokban a gazdag régiók népessége nő gyorsabban, a szegény országokban pedig a szegényebbeké. A népességarányok változása a gazdag országokban a térbeli kiegyenlítődés irányába hat, a szegényekben a különbségek növekedése irányába.

A régió 16 nemzet fö lakóterülete, de további 8, más meghatározás szerint 10 egyéb nemzethez tartozó kisebbség él itt. Az önálló állammal rendelkező nemzetek népességének jelentős hányada kisebbségben is él. Az egyik legnagyobb európai kisebbségnek, a romáknak, kiknek létszámát 6-8 millióra teszi, külön alfejezetet is szentel legfőképpen azért, mert ez a népcsoport tükrözi az átmenet teljes problémaspektrumát, következésképpen reális fejlesztési programot készíteni nem lehet akkor, ha nem vesszük figyelembe a roma lakosság egészen specifikus problémáit hangsúlyozza Illés Iván. Ezen túlmenően a probléma történelmi előzményeit tárgyalva kiemeli, hogy a romák egyes országokban kétszeres értelemben is kisebbséget alkotnak: a szlovákiai romák egy része magyarul beszél, míg a csehországiak egy része szlovákul, a magyarországiak egy része románul, a romániaiak egy része magyarul.

A könyv olvasása során döbbenünk rá arra, amit Magyarország esetében már régen tudunk, hogy a rendszerváltás után az egész térség politikai tagoltságában a regionális faktornak meghatározó szerepe van.

Önkéntelenül is összehasonlítva ezt a könyvet a sorozatban korábban megjelent, szakmai szempontból szintén kiváló mủvekkel, a legnagyobb erényét a már említett hatalmas és differenciált földrajzi terület elemzése mellett az interdiszciplináris megközelítésben látjuk. Illés Iván a vizsgált témát illetően egyaránt járatos a történelem, a földrajz, a politológia, a közgazdaság és az etnikai, szociológiai tudományok szempontjainak alkalmazásában. Bizonyítva ezzel a regionális tudomány interdiszciplinaritását és a regionális fejlesztés komplexitását.

Gazdasági szempontból nézve, a könyvben talán legérdekesebb az a táblázat, amely a GDP alapján mért gazdasági fejlettséget mutatja a „rövid XX. század” elején és végén. Természetesen - írja a Szerzö - 1913-ban is voltak a térségben fejlettségbeli különbségek, de ezek viszonylag szükebb határok között maradtak. A 
legalacsonyabb (Bulgária) és a legmagasabb (Németország) szint közötti különbség 2,8-szeres volt. 1993-ban, ha a valutaárfolyam szerint mért GDP-különbségektöl eltekintünk, akkor is látható, hogy a vásárlóerő szerinti különbség kétszer akkora, mint 1913-ban, 5,3-szeres. A leglényegesebb változás Olaszország és Csehország helyzetében tapasztalható. Az európai átlaghoz viszonyítva Csehország elmozdulása 59 ponttal lefelé, Olaszországé 73 ponttal felfelé történt. A tendencia egyértelmü, valamennyi „nyugati” ország - beleértve Görögországot is - felfelé, valamennyi keleti ország lefelé mozdult el ezen a skálán. Minden jel arra mutat, hogy a szovjet hegemónia alatt töltött negyven év olyan örökséget hagyott hátra a politikai, gazdasági, jogi és emberi viszonylatokban, magatartásformákban, amelyek meghaladása nehezebbnek bizonyult a várakozásnál - ezt leglátványosabban Németország két fele bizonyítja -, és amelynek hatásaival még jó ideig számolni kell. Ezen belül is írja egy másik helyen a Szerzö - a szovjet típusú gazdasági rendszer bevezetését megelőzően Szászország a Rajna-vidék után Németország második legfejlettebb és leggazdagabb tartománya volt, kulturális szempontból pedig talán az első. A szovjet típusú gazdasági rendszer bevezetése során a legnagyobb visszalépés ebben a tartományban következett be.

A könyvben az interdiszciplinaritás nemcsak a több tudományterületi megközelítés egymásra épülő alkalmazásában nyilvánul meg, hanem abban is, hogy a Szerző nagyon sok területen kíséri végig a regionális különbségek és hasonlóságok alakulását a vizsgált térségben. Ezek közül íme csak ötletszerüen néhány: a privatizáció, a mezőgazdaság, a városi és vidéki területek problémái, a környezet állapota, és különösen nagy teret kap a közlekedésfejlesztés.

A Szerző szerint a bövítésre irányuló döntés alapvetően az Unió döntése. Illés Iván belülröl ismeri a keleti bövítés esélyeit, hiszen három évig az Európai Unió „székéből látta” ezt a folyamatot. Álláspontját objektívnek lehet definiálni. A bővítést illetően mindenesetre nincsenek illúziói, és kimenetelével kapcsolatban három forgatókönyvet vázolt fel, mindegyiknek vannak pozitívumai és negatívumai. Ezeknek a forgatókönyveknek az alábbi neveket adta:

1. „Eurorealizmus"

2. "Az integráció kudarca"

3. "Félbemaradó integráció"

Ma, az idö múlásával az olvasó azt a következtetést is levonhatja, hogy legnagyobb esélye a harmadik forgatókönyv megvalósulásának van.

E forgatókönyv szerint a térségen belül az egyes országcsoportok külön úton haladnak. A differenciálódás, ami a térség országai között az elmúlt tíz évben megfigyelhető volt, folytatódik, sőt felerösödik. Bár Magyarország a bebocsátottak első csoportjában lesz, és ez hízelgő is számára, mégis, Illés Iván hite szerint hazánk a leginkább abban érdekelt, hogy ne ez a forgatókönyv valósuljon meg. Ezzel a gondolattal zárul a monográfia első része, amelyben a számtalan pozitívum mellett talán egy apró hiányosság is van. Nem található ebben a részben a leírtak szemléltetéseként térkép, illetve ábra. 
Tér és Társadalom 16. évf. 2002/1. 161-177. p.

A könyv második része az utolsó, a negyedik fejezettel megegyezik. E fejezet címe „Transznacionális régiók Közép- és Délkelet-Európában”. A „transznacionális” szó - írja a Szerzö - a nemzetközi területfejlesztési zsargon új eleme. A transznacionalitás bizonyos értelemben a nemzetállami kizárólagosság megkérdőjelezése. A földrajzi közelség, egymás melletti elterülés, a megoldatlan környezeti, gazdasági, közlekedési és politikai kölcsönhatások eredményezik ezt a folyamatot, amely napjaink nagy kihívása, függetlenül attól, hogy az érintett nemzetállamok akár akarják és szeretik ezt, akár nem. Az ilyen térségekre vonatkozó problémák nem globálisak, nem is összeurópaiak, hanem egy szükebb, földrajzilag lehatárolható térre koncentrálódnak. A transznacionális régiók két típusáról olvashatunk. Az egyik az alábbi hat közép- és délkelet-európai nagyléptékü, közös eröfeszítést és megoldást igénylő probléma, illetve földrajzi terület:

1. a Közép-európai Interakciós Övezet;

2. Délkelet-Európa;

3. a Kárpát Régió;

4. az Adriai-tengeri Régió;

5. a Fekete-tengeri Együttmüködési Övezet;

6. a Duna menti régiók együttmüködése.

A transznacionális régiók második típusát alkotják a kisebb kiterjedésủ, de több mint két ország területén találkozó és egymásba fonódó közlekedési, infrastrukturális, környezeti és természetvédelmi problémákkal terhelt területek, amelyek legalább háromoldalú egyeztetést, közös tervezést és fejlesztést igényelnek. Illés Iván kiemeli, hogy egész Európában 25 ilyen térség van, és ezeknek kétharmada Középés Délkelet-Európában található, melyeket „határ menti akcióterületeknek" nevez, és közülük öt többek között Magyarországra is kiterjed. Ezek az alábbiak: Kárpátalja - Galícia határ menti régió, Duna-Dráva-Száva négyes határ menti régió, RábaMura négyes határkörzet, Duna-Morva-Vág négyes határterület, Bácska-Bánát hármas határrégió. Valamennyi határ menti akcióterület esetében olvashatunk a térség földrajzi és történelmi-politikai helyzetéről, az infrastruktúráról, helyenként még a környezeti és természeti értékekröl, a kulturális örökségről, illetve a gazdaságról.

Összegzésként: a Közép-és Délkelet-Európa az ezredfordulón címü monográfia gazdag ismeretanyagot tartalmazó kiváló szakmai munka. Mivel szép, irodalmi stílusban megírt, olvasmányos mü, ezért méltán számíthat nemcsak a szakmai, tudományos, hanem a szélesebb olvasóközönség érdeklödésére is. 